$$
\text { z zprávy }
$$





\section{0 let po pádu železné opony}

Ve dnech 6. a 7. února 2020 se v jihofrancouzském Aix-en-Provence uskutečnila mezinárodní konference s názvem 30 let po pádu železné opony, kterou pořádala Aix-Marseille Université, Faculté des Arts, Lettres, Langues et Sciences humaines. Setkali se na ní politici, politologové, diplomaté, historici, literární vědci, překladatelé a zástupci př́ibuzných oborů z Francie, Rakouska a České republiky. Řečníci vystoupili během čtvrtečního odpoledne a pátečního dopoledne ve čtyřech blocích a program doplnilo večerní promítání dokumentárního filmu.

Na úvod konference organizátoři uspořádali kulatý stůl, jejž moderoval Lukáš Macek, ředitel Sciences Po de Dijon, a u nějž hovořili Jeho Excelence Michael Linhart, velvyslanec Rakouska ve Francii, František Med, rada vyslanec, zástupce vedoucího úřadu na Velvyslanectví České republiky, Jacques Rupnik, ředitel výzkumu Sciences Po de Paris, bývalý poradce prezidenta České republiky Václava Havla, a Charles Zaremba, profesor na katedře slavistiky Aix-Marseille Université. Jednotliví diskutující ve svých úvodních výpovědích shrnuli zkušenosti a názory získané za dobu působení ve vrcholné politice nebo během výzkumu středoevropského prostoru. Michael Linhart hovořil např. o roli Rakouska v rozdělené Evropě do roku 1989; Jacques Rupnik vzpomínal na setkání sedmi prezidentů Visegradu v Litomyšli roku 1994, době, kdy střední Evropa výrazně měnila svou tvář, vznikaly nové státy a utvářely se nové vzájemné vztahy; František Med představil naši současnou kulturní politiku ve Francii.

První přednáškový blok byl věnován oblasti kultury. Zahájil jej Alexander Burka (CIVIC GmbH - Institut für internationale Bildung) příspěvkem zaměřeným na vývoj zahraniční kulturní politiky Rakouska v České republice a Polsku, zvláště se soustředil na situaci před rokem 1989 a na tehdejší spolupráci rakouských institucí s československými a polskými umělci. V následujícím referátu, tematicky zasazeném rovněž před rok 1989, popisovala Catherine Teissier (Aix-Marseille Université) filmovou tvorbou v Německé demokratické republice zabývající se politickou situací během posledních let před pádem berlínské zdi. 
Druhý blok soustředil témata literární. Xavier Galmiche (Université Paris IV - Sorbonne) přednesl příspěvek Globální fenomén, národní zvláštnosti: charakteristika českého (a slovenského) samizdatu v protikultuře od 50. do 80 . let. Vysvětlil původ a specifika samizdatu, jmenoval jeho nejvýraznější české představitele a některé samizdatové edice. Svou přednášku podložil několika publikacemi, zejména knihou Michala Přibáně a kol. Český literární samizdat: 1949-1989, kterou publiku představil jako mimořádný a cenný soubor faktů obohacený o dosud neznámé zajímavosti. Dnes je to nenahraditelný zdroj pramenných informací k dějinám české nezávislé kultury. Dagmar Vobecká (Ústav pro českou literaturu AV ČR) představila Rakouskou společnost pro literaturu jako partnera českých a slovenských autorů v době studené války. Vycházejíc z korespondence mezi touto společností a Václavem Havlem ukázala jednotlivé způsoby spolupráce - distribuci západní literatury, autorská čtení, studijní stipendia či pomoc spisovatelům při uvedení na rakouskou uměleckou scénu. Posledním v tomto bloku byl s názvem 1989 - postavy a místa v přerodu pohledem rumunským, mad'arským a německým příspěvek dvojice Mónika Dánél (Universitetet i Oslo) a Stephan Krause (Leibniz-Institut für Geschichte und Kultur des östlichen Europa). Společně nabídli několik příkladů ztvárnění změny režimu v uvedených třech národních literaturách.

První konferenční den ukončilo večerní promítání dokumentárního filmu Prague, le mois de la liberté, který pro francouzskou TF1 v roce 1989 v Praze natočili Michael Wellner Pospíšil a Patrick Volson. Snímek zachycuje život několika postav nejprve zkraje uvedeného roku a pak ve dnech sametové revoluce.

Páteční program byl rozdělen opět do dvou bloků. Část věnovanou historii a pamětem zahájil Alain Soubigou (Université Paris I Panthéon-Sorbonne) referátem Pád komunismu ve střední a východní Evropě: zázrak nebo přelud? $S$ podporou bohaté doprovodné prezentace ukázal velmi emotivním a názorným způsobem východoevropský politický a kulturní přerod. Charles Zaremba zaměřil svůj pohled na nedávnou historii Polska a popsal četné změny, jimiž v posledních třiceti letech tato země prošla. Céline Bricaire (Aix-Marseille Université) se v př́ispěvku 1989 v kultuře a komunikaci v Mad'arsku dnes: vzpomínky a politika věnovala mad'arským oslavám výročí pádu železné opony, resp. interpretaci událostí z roku 1989 a s tím spojené kampani současné vlády v Mad'arsku v čele s Victorem Orbánem.

Poslední, čtvrtý blok byl věnován tématům didaktickým. Jiří Hnilica (České centrum v Pařiži) hovořil o významu Českého centra v Paříži. Jeho posláním je spolupráce $s$ francouzskou veřejností a prezentace české kultury, vědy, škol- 
ství, obchodu a cestovního ruchu. Centrum je příspěvkovou organizací Ministerstva zahraničních věcí a pod jeho záštitou vznikl v roce 2003 projekt České školy bez hranic, který se $\mathrm{z}$ Pařiže rozrostl do dalších evropských měst. České centrum nabízí rovněž kurzy českého jazyka pro dospělé. Přednáškou s názvem Sociokulturní aspekty výuky českého jazyka v Rakousku od roku 1989 navázala v oblasti vzdělání, konkrétně translatologie, Michaela Kuklová (Universität Wien). Poslední referát nejen této části, ale celé konference přednesla Katharina Jechsmyar (Aix-Marseille Université) a zabývala se $\mathrm{v}$ něm výkladem pádu železné opony v rakouských učebnicích. Závěrečná diskuse se nejvíce točila kolem nutnosti a způsobů prezentace české kultury a literatury v zahraničí a také výuky českého jazyka, jeho propagace a většího zatraktivnění v cizině.

Organizátoři předpokládají ještě $\mathrm{v}$ tomto roce digitální zpřístupnění všech konferenčních příspěvků.

Dagmar Vobecká 
